\title{
Pengaruh Penggunaan Media Kotak Pas Bangun Ruang Pada Tema Kegemaranku Terhadap Hasil Belajar Siswa
}

\author{
Gestari Ayu Dewanti ${ }^{*}$, Ary Susatyo Nugroho ${ }^{2}$, Khusnul Fajriyah ${ }^{3}$ \\ 123 Program Studi Pendidikan Guru Sekolah Dasar, Fakultas Ilmu Pendidikan, Universitas PGRI Semarang
}

\section{A R T I CLEINFO}

Article history:

Received 18 August 2019

Received in revised form

19 September 2019

Accepted 25 October 2019

Available online 30

November 2019

Kata Kunci:

Kotak Pas Bangun Ruang,

Hasil Belajar

Keywords:

Fitting Box Building Space, Learning Outcomes
A B S T R A K

Tujuan yang dicapai adalah mendeskripsikan Pengaruh Media Kotak Pas Bangun Ruang pada Tema Kegemaranku terhadap hasil belajar siswa kelas I SDN 1 Karangasem Kabupaten Grobogan. Jenis penelitian ini adalah penelitian kuantitatif. Desain penelitian yang digunakan dalam penelitian ini adalah Pre-Eksperimental Design dengan bentuk One Grup Pretest-Posttest Design. Populasi penelitian ini adalah seluruh siswa kelas I SDN 1 Karangasem Kabupaten Grobogan. Sampel yang diambil adalah siswa dari kelas I SDN 1 Karangasem Kabupaten Grobogan yang berjumlah 14 orang dengan menggunakan teknik Non Probability Sampling yang merupakan jenis sampling jenuh. Data dalam penelitian ini diperoleh melalui tes, dokumentasi dan wawancara. Hasil belajar siswa kelas I menggunakan Media Kotak Pas Bangun Ruang pada Tema Kegemaranku, diperoleh nilai rata-rata pretest sebesar 56,43 dengan nilai tertinggi 75 dan nilai terendah 40. Nilai rata-rata posttest sebesar 75,36 dengan nilai tertinggi 100 dan nilai terendah 55. Berdasarkan hasil perhitungan data akhir nilai posttest diperoleh $L_{\text {hitung }}=0,1451$ dengan $n=14$ dan taraf nyata $\alpha$ $=0,05$ atau $5 \%$ dari daftar nilai kritis $L$ didapat $L_{\text {tabel }}=0,227$, karena $L_{\text {hitung }}<L_{\text {tabel }}$ yaitu $0,1451<0,227$ maka $\mathrm{H}_{0}$ diterima, sehingga dapat disimpulkan bahwa bahwa sampel berasal dari populasi berdistribusi normal. Dari data hasil pretest dan posttest memenuhi kriteria pengujian karena keduanya berdistribusi normal .Berdasarkanuji- $t$ diperoleh $t_{\text {hitung }}>$

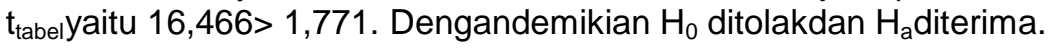

\section{A B S T R A C T}

The goal achieved is to describe the Effect of the Media Box Pas Build Space on the Theme of My Love to the learning outcomes of students of class I SDN 1 Karangasem Grobogan Regency. This type of research is quantitative research. The research design used in this study was PreExperimental Design in the form of One Group Pretest-Posttest Design. The population of this study was all students of class I SDN 1 Karangasem Grobogan Regency. The sample taken was students from class I SDN 1 Karangasem Grobogan Regency, amounting to 14 people by using the Non Probability Sampling technique which is a type of saturated sampling. Data in this study were obtained through tests, documentation and interviews. Class I student learning outcomes using the Media Box Pas Build Space on My Love Theme, obtained an average pretest score of 56.43 with the highest value of 75 and the lowest value of 40 . The average posttest score of 75.36 with the highest value of 100 and the lowest value 55. Based on the results of the final data calculation, the posttest value is obtained Lhitung $=0.1451$ with $n=14$ and the real level $\alpha=0.05$ or $5 \%$ of the list of critical values $L$ is obtained Ltable $=0.227$, because Lhitung $<$ Ltable is $0.1451<0.227$ then $\mathrm{HO}$ is accepted, so it can be concluded that the sample comes from normally distributed populations. From the results of the pretest and posttest results meet the test criteria because they are normally distributed. Based on the $\mathrm{t}$-test, it is obtained tcount> ttable, that is $16.466>1.771$. With this, $\mathrm{H} 0$ was rejected and Hadit was accepted

\footnotetext{
${ }^{1}$ Corresponding author.

E-mail addresses: gestari11@gmail.com (Gestari Ayu Dewanti)
} 


\section{Pendahuluan}

Pendidikan merupakan hal terpenting dalam kehidupan, apalagi dalam era globalisasi sekarang ini. Seseorang yang menempuh pendidikannya dengan baik akan terlihat kesungguhannya dalam kesehariannya. Pendidikan tidak hanya dilakukan di dalam ruangan dengan seorang pendidik dan yang di didik, tetapi dapat dilakukan dimananpun dan kapanpun, agar mewujudkan proses pembelajaran secara aktif dan mengembangkan potensi dirinya. (Sukmadinata, 2009:3) mengungkapkan bahwa pendidikan pada dasarnya merupakan interaksi antara pendidik dengan peserta didik, untuk mencapai tujuan pendidikan, yang berlangsung dalam lingkungan tertentu. Sedangkan menurut (Purwanto,2003:10) pendidikan ialah pimpinan yang diberikan dengan sengaja oleh orang dewasa kepada anak-anak, dalam pertumbuhannya (jasmani dan rohani) agar berguna bagi diri sendiri dan bagi masyarakat. UndangUndang No.20 Tahun 2003 Pasal 1 Ayat 1 mengungkapkan bahwa Pendidikan adalah usaha sadar dan terencana untuk mewujudkan suasana belajar dan proses pembelajaran agar peserta didik secara aktif mengembangkan potensi dirinya untuk memiliki kekuatan spiritual keagamaan, pengendalian diri, kepribadian, kecerdasan, akhlak mulia, serta keterampilan yang diperlukan dirinya, masyarakat, bangsa dan Negara.

Nasution (2000) berpendapat bahwa guru bertanggung jawab untuk menyediakan lingkungan yang paling serasi agar terjadi proses belajar yang efektif. Oleh karena itu guru harus pandai mengelola kelas agar peserta didik dapat berperan aktif dalam pembelajaran. Karena apabila peserta didik tidak berperan aktif dalam pembelajaran, akan berdampak terhadap ketuntasan belajar yang tidak tercapai. Untuk itu diperlukan kreatifitas seorang guru untuk mengembangkan proses pembelajaran yaitu dengan metode dan media yang tepat dalam proses belajar mengajar di kelas (Maslikan, 2017).

Matematika adalah salah satu pelajaran dari beberapa mata pelajaran yang mempunyai peran penting dalam pendidikan. Matematika salah satu bidang studi yang mendukung perkembangan ilmu pengetahuan dan teknologi. Pada kenyataan matematika sebagai mata pelajaran yang sulit, membosankan serta tidak menyenangkan, bahkan menakutkan. Hal ini dikarenakan masih banyak siswa yang mengalami kesulitan-kesulitan dalam pembelajaran matematika.

Marti (dalam Sundayana, 2015:3) berpendapat bahwa obyek matematika yang bersifat abstrak merupakan kesulitan tersendiri yang harus dihadapi siswa dalam mempelajari matematika. Obyek-Obyek Matematika dapat di pahami dengan mudah apabial bersifat konkrit, makak pengajaran matematika harus dimulai dari tahapan konkret kemudian diarahkan pada tahapan semi konkret, dan pada akhirnya siswa dapat berfikir dan memahami matematika secara abstrak. Untuk menciptakan proses pembelajaran yang berkualitas, guru seringkali menemukan kesulitan dalam mengajarkan matematika terkait sifatnya yang abstrak tersebut.

Untuk mengantisipasi kebosanan siswa dalam pembelajaran di kelas, guru perlu mengembangkan pembelajaran yang aktif dan inovatif, guna meningkatkian hasil belajar matematika siswa. Pemilihan pendekatan, model, metode, strategi, media, maupun tekhnik pembelajaran oleh guru akan mempengaruhi pembelajaran yang dilaksanakan di kelas.

Berdasarkan hasil wawancara dengan Guru Kelas I SDN 1 Karangasem Kabupaten Grobogan yaitu Ibu Sapta Puspitasari, S.Pd.SD. Dapat di simpulkan bahwa kurangnya keaktifan dan pemahaman siswa saat pembelajaran berlangsung karena jarang sekali menggunakan media pembelajaran, sehingga pembelajaran kurang nyata dan kurang menarik. Yang di harapkan Ibu Sapta Puspitasari, S.Pd.SD setiap pembelajaran ada media yang di gunakan, sehingga pembelajaran menjadi lebih jelas dan nyata, lebih interaktif, efisien dalam waktu dan tenaga. Sarana prasarana yang kurang mendukung juga mempengaruhi hasil belajar siswa kelas I SDN 1 Karangasem Kabupaten Grobogan.

Media kotak pas bangun ruang yaitu media pembelajaran yang dapat diamati dengan mudah serta dapat dimainkan oleh siswa kelas 1 . Media tersebut berupa kotak yang berlubang membentuk persegi panjang, persegi, segitiga dan lingkaran serta bentuk-bentuk bangun ruang seperti kubus, balok, prisma segitiga, dan bola. Penggunaan dan pemanfaatannya cukup sederhana, karena tidak perlu khusus pembuatannya, guru bisa memanfaatkan bahan yang ada di sekitar. Materi yang di pilih dalam penelitian ini adalah materi pada tema kegemaranku. Agar siswa dapat memahami materi tersebut maka media kotak pas bangun ruang diperlukan. Melalui media kotak pas bangun ruang tersebut diharapkan siswa dapat belajar dan bermain sehingga pembelajaran dapat aktif dan menyenangkan.

Pembelajaran tematik yaitu pembelajaran yang menggunakan tema untuk mengaitkan beberapa mata pelajaran sehingga dapat memberikan pengalaman yang bermakna bagi siswa. Tema yang akan di pilih yaitu tema 2 "kegemaranku" karena dalam tema tersebut siswa susah untuk memahami materi yang diajarkan oleh guru. 
Berdasarkan hasil wawancara dengan guru kelas dapat diidentifikasikan bahwa : 1) sarana prasarana kurang mendukung, 2) Kurangnya keaktifan dan pemahaman siswa sehingga mrmbutuhkan media pembelajaran yang nyata dan menarik, 3) Kurang pemanfaatan media pembelajaran.

Penyebab kurangnya keaktifan dan pemahaman siswa kelas I antara lain yaitu guru belum menggunakan pendekatan yang berpusat pada siswa sehingga dalam pembelajaran siswa yang aktif lebih sedikit di banding siswa yang pasif, kurangnya pemanfaatan alat peraga atau media pembelajaran untuk memepermudah siswa, sarana prasarana yang kurang mendukung, sulitnya siswa memahami materi matematika yang abstrak. Dengan adanya media, maka siswa akan lebih memahami materi dan lebih aktif dalam pembelajaran karena siswa membutuhkan contoh yang konkrit. Usia kelas 1 adalah usia yang belum memahami materi dengan hanya menggunakan gambar saja, siswa perlu contoh yang nyata.

Langkah yang dapat dilakukan untuk mengatasi masalah tersebut adalah memilih media yang kreatif, menyenangkan, sesuai dengan karakteristik siswa dan dapat dengan mudah di pahami oleh siswa. Dengan menggunakan stategi pembelajaran baru, maka siswa akan merasa belajar matematika merupakan kegiatan yang menyenangkan, diharapkan pembelajaran lebih efektif dan hasil belajar siswa lebih baik. Sebagai upaya meningkatkan hasil belajar siswa kelas I SDN 1 Karangasem Kabupaten Grobogan, penelitian ini menggunakan media kotak pas bangun ruang.

Sesuai dengan masalah di atas, tujuan penelitian ini adalah mendeskripsikan pengaruh media kotak pas bangun ruang pada tema kegemaranku terhadap hasil belajar siswa kelas I SDN 1 Karangasem Kabupaten Grobogan

Gagne dalam Mudjiono (2009:10) mengungkapkan belajar pada hakikatnya merupakan kegiatan yang kompleks.Hasil belajar berupa kapabilitas.Setelah belajar memiliki keterampilan, pengetahuan, sikap, dan nilai. Hal tersebut timbul stimulasi dari lingkungan dan proses kognitif yang dilakukan oleh pembelajar.

Slameto (2003:2) menyatakan bahwa belajar ialah suatu proses usaha yang dilakukan seseorang untuk memperoleh suatu perubahan tingkah laku yang baru secara keseluruhan, sebagai hasil pengalamannya sendiri dalam interaksi dengan lingkungannya.

Hamalik (2009: 27) mengatakan belajar adalah modifikasi atau memperteguh kelakuan melalui pengalaman. Suatu proses kegiatan dan bukan hasil atau tujuan. Belajar bukan hanya mengingat, akan tetapi lebih

Seseorang dikatakan telah belajar kalau sudah terdapat perubahan tingkahlaku dalam dirinya.Kecuali itu, perubahan tersebut haruslah bersifat relatif permanen, tahan lama, dan menetap, tidak berlangsung sesaat saja. Belajar memiliki ciri-ciri sebagai berikut: a) adanya kemampuan baru dan perubahan yang bersifat pengetahuan, keterampilan, maupun nilai sikap, b) perubahan yang menetap atau dapat di simpan, c) perubahan tidak terjadi begitu saja, melainkan harus dengan usaha. Perubahan terjadi akibat interaksi dengan lingkungan, d) perubahan terjadi tidak semata-mata disebabkan oleh pertumbuhan fisik atau kedewasaan, tidak karena kelelahan, penyakit atau pengaruh obat-obatan, Nara (2011: 5).

Sedangkan menurut Mudjiono (2009: 8) cirri-ciri belajar ialah: a) siswa yang bertindak belajar atau pebelajar, b) memperoleh hasil belajar dan pengalaman hidup, c) internal pada diri pebelajar, d) sembarang tempat, e) sepanjang hayat, f) motivasi belajar kuat, g) dapat memecahkan masalah, h) bagi pebelajar mempertinggi martabat pribadi, i) hasil belajar sebagai dampak pengajaran dan pengiring.

Siswa SD umurnya berkisar antara 6 atau 7 tahun, sampai 12 atau 13 tahun, mereka berada pada fase operasional konkret. Kemampuan yang tampak pada fase ini adalah kemampuan dalam proses berfikir untuk mengoperasikan kaidah-kaidah logika, meskipun masih terkait dengan objek yang bersifat konkret, Piaget dalam Heruman (2014: 1)

Hasil belajar merupakan sesuatu yang diperoleh siswa setelah mengikuti proses pembelajaran. Menurut Kunandar (2007) "hasil belajar adalah kemampuan siswa dalam memenuhi suatu tahapan pencapaian pengalaman belajar dalam satu kompetensi dasar". Menurut Abdurrahman (2003), "hasil belajar adalah kemampuan yang diperoleh anak setelah melalui kegiatan belajar". Sedangkan menurut Romiszowski (dalam Abdurrahman, 2003) menyatakan bahwa: "Hasil belajar adalah keluaran (output) dari suatu sistem pemrosesan masukan (input). Masukan dari sistem tersebut berupa bermacam-macam informasi sedangkan keluarannya adalah perbuatan atau kinerja (performance)".

Menurut Bloom (dalam Suprijono, 2011) menyatakan bahwa: Hasil belajar mencakup kemampuan kognitif, afektif, dan psikomotorik. Domain kognitif adalah knowledge (pengetahuan, ingatan), compherension (pemahaman, menjelaskan, meringkas, contoh), application (menerapkan), analysis (menguraikan, menentukan hubungan), synthesis (mengorganisasikan, merencanakan, membentuk, bangunan baru), dan evaluation (menilai). Domain afektif adalah receiving (menerima), responding (memberikan respon), valuing (nilai), organization (organisasi), characterization (karakteristik). Domain 
psikomotorik mencakup keterampilan produktif, teknik, fisik, sosial, manajerial, dan intelektual (Ayuwanti, 2016).

Sedangkan menurut Heruman (2014: 2) konsep-konsep pada kurikulum matematika SD dapat dibagi menjadi 3 kelompok besar, yaitu pemahaman konsep dasar (penanaman konsep), pemahaman konsep, dan pembinaan keterampilan.

Heruman (2014: 1) mengemukakan bahwa siswa Sekolah Dasar (SD) umurnya berkisar antara 6 atau 7 tahun, sampai 12 atau 13 tahun. Menurut Piaget, mereka berada pada fase operasional konkret. Kemampuan yang tampak pada fase ini adalah kemampuan dalam proses berpikir untuk mengoperasikan kaidah-kaidah logika, meskipun masih terikat dengan objek yang bersifat konkret.

Ruseffendi dalam Heruman(2014: 1) Matematika adalah bahasa simbol ilmu deduktif yang tidak menerima pembuktian secara induktif, ilmu tentang pola keteraturan, dan struktur yang terorganisasi, mulai dari unsur yang tidak di definisikan, ke unsur yang di definisikan, ke asioma atau postulat dan akhirnya ke dalil.

Sedangkan hakekat matematika menurut Soedjadi dalam Heruman (2014: 1) yaitu memiliki objek tujuan abstrak, bertumpu pada kesepakatan, dan pola pikir yang deduktif.

Arsyad (2014: 3) mengemukakan kata media berasal dari bahasa latin medius yang secara harfiah berarti 'tengah', 'perantara' atau 'pengantar pesan dari pengirim kepada penerima pesan. Gerlach \& Ely dalam Arsyad (2014: 3) mengatakan bahwa media apabila dipahami secara garis besar adalah manusia, materi, atau kejadian yang membangun kondisi, yang membuat siswa mampu memperoleh pengetahuan, keterampilan, atau sikap.

Fleming dalam Arsyad (2014: 3) menyatakan bahwa media adalah penyebab atau alat yang turut campur tangan dalam dua pihak dan mendamaikannya. Heinich et. aldalam Arsyad (2014: 3) berpendapat bahwa istilah medium sebagai perantara yang mengantar informasi antara sumber dan penerima.

Dari pengertian tersebut dapat disimpulkan secara umum pengertian media adalah alat yang digunakan untuk menyalurkan informasi dari sumber ke penerima.Dalam hal ini dapat ditarik kesimpulan bahwa pengertian media pembelajaran sebagai sarana untuk memberikan informasi dalam bentuk pengetahuan yang berasal dari mana saja.

Pembelajaran tematik adalah program pembelajaran yang berangkat dari satu tema atau topik tertentu dan kemudian dielaborasi dari berbagai aspek atau ditinjau dari berbagai perspektif mata pelajaran yang bisa di ajarkan di sekolah. Menurut Kurniawan (2014:95) pembelajaran tematik adalah salah satu bentuk atau model dari pembelajaran terpadu, yaitu model terjala (webbed). Yang pada intinya menekankan pada pola pengorganisasian materi yang terintegrasi dipadukan oleh satuan tema. Tema diambil dan dikembangkan dari luar mata pelajaran, tapi sejalan dengan kompetensi dasar dan topiktopik dari mata pelajaran. Model tematik sebagai alternatif dari pola organisasi materi yang sudah sangat tua dan lazim digunakan didunia pendidikan yaitu discrete subject atau separated curriculum. Keberhasil model pembelajaran terpadu:tematik itu sendiri, diantaranya sangat dipengaruhi oleh keterterapan prinsip-prinsip pembelajaran terpadu:tematik itu sendiri.

Pembelajaran tematik dirancang dalam rangka meningkatkan hasil belajar yang optimal dan maksimal dengan cara mengangkat pengalaman anak didik yang mempunyai jaringan dari berbagai askpek kehidupannya dan pengetahuannya. Mengintegrasikan antara satu pengalaman dengan pengalaman yang lain atau antara satu pengetahuan dengan pengetahuan yang lain bahkan antara pengalaman dengan pengetahuan dan sebaliknya memberikan kebermaknaan dalam pembelajaran dalam arti bahwa pembelajaran itu memberikan fungsi yang berguna bagi kehidupan siswa.

\section{Metode}

Penelitian ini di laksanakan pada semester ganjil pada bulan Oktober tahun ajaran 2019/2020. Dalam penelitian ini peneliti menggunakandua variabel yang terdiri dari variabel bebas dan variabel terikat. Variabel bebas dalam penelitian ini adalah media kotak pas bangun ruang dan variabel terikat dalam penelitian ini adalah hasil belajar siswa kelas I pada tema kegemaranku.

Desain penelitian ini menggunakan desain penelitian pre-eksperimental designs dengan bentuk OneGroup-Pretest-Posttest Design yang terdapat Pretest sebelum di berikan perlakuan dengan Posttest sesudah di berikan perlakuan. Dengan demikian hasil penelitian dapat di ketahui lebih akurat, karena dapat membandingkan keadaan sebelum di beri perlakuan dan sesudah di beri perlakuan.

Desain ini juga sering di sebut sebagai eksperimen semu. Karena masih terdapat variabel luar yang ikut berpengaruh terhadap terbentuknya variabel dependen. Hal ini dapat terjadi karena tidak adanya variabel kontrol dan sampel yang tidak di pilih secara random.

Populasi penelitian adalah wilayah generalisasi yang terdiri atas objek/subjek yang mempunyai kualitas dan karakteristik tertentu yang ditetapkan oleh peneliti untuk dipelajari dan kemudian di tarik 
kesimpulan (Sugiyono,2015: 117). Sebagai populasi yang direncanakan dalam penelitian ini adalah siswa kelas I di SD Negeri 1 Karangasem Kabupaten Grobogan yang berjumlah 14 siswa.

Dari populasi tersebut, diambil sampel yaitu kelas I yang terdiri dari 14 siswa dan ditetapkan sebagai kelas eksperimen yang mendapatkan pembelajaran dengan media kotak pas bangun ruang, dalam penelitian ini, peneliti menggunakan sampling jenuh.

Salah satu teknik pengumpulan data yang di gunakan adalah tes. Tes yang digunakan pada penelitian ini adalah pretest yang di berikan pada saat kelas belum di berikan perlakuan, dan posttest yang di berikan di akhir setelah siswa mendapat perlakuan.

\section{Hasil dan Pembahasan}

Pada data ini akan melakukan Uji Normalitas. Data hasil peneitian dilakukan uji normalitas dengan menggunakan uji liliefors untuk mengetahui data berasal dari populasi yang berdistribusi normal atau tidak. Uji normalitas dilakukan pada nilai Pretest siswa dengan hipotesis sebagai berikut

Tabel 1. Hasil Data Uji Normalitas Pretest

\begin{tabular}{lll}
\hline NO & DATA & \\
\hline 1 & Jumlah & 790 \\
2 & Rata-rata & 56,43 \\
3 & S & 10,082 \\
4 & Lo & 0,1271 \\
5 & L tabel & 0,227 \\
\hline
\end{tabular}

Kesimpulan : $\mathrm{L}_{0}<$ Ltabel maka $\mathrm{H}_{0}$ diterima artinya data berdistribusi normal. Berdasarkan data hasil perhitungan yaitu uji normalitas Pretest pada kelas I SD Negeri 1 Karangasem Kabupaten Grobogan didapatkan nilai $\mathrm{L}_{\text {hitung }}$ sebesar 0,1271 sedangkan $\mathrm{L}_{\text {tabel }} 0,227$. Berarti $\mathrm{L}_{\text {hitung }} 0,1271<\mathrm{L}_{\text {tabel }} 0,227$ maka $\mathrm{H}_{0}$ diterima. Hal ini berarti sampel berasal dari populasi berdistribusi normal

Pada data ini akan melakukan Uji Normalitas. Data hasil penelitian dilakukan uji normalitas denggan menggunakan uji liliefors untuk mengetahui data berasala dari populasi yang berdistribusi normal atau tidak. Uji normalitas dilakukan pada nilai Posttest siswa dengan hipotesis sebagai berikut

Tabel 2. Hasil Data Uji Normalitas Posttest

\begin{tabular}{lll}
\hline NO & DATA & \\
\hline 1 & Jumlah & 1055 \\
2 & Rata-rata & 75,36 \\
3 & S & 12,929 \\
4 & Lo $_{0}$ & 0,1451 \\
5 & Ltabel & 0,227 \\
\hline
\end{tabular}

Kesimpulan : $\mathrm{L}_{0}<\mathrm{L}_{\text {tabel }}$ maka $\mathrm{H}_{0}$ diterima artinya data berdistribusi normal. Berdasarkan hasil perhitungan normalitas yaitu uji normalitas Posttest pada kelas I SD Negeri 1 Karangasem Kabupaten Grobogan didapatkan nilai $\mathrm{L}_{\text {hitung }}$ sebesar 0,159 dengan harga $\mathrm{L}_{\text {tabel }}=0,161$. Berarti $\mathrm{L}_{\text {hitung }} 0,1451<\mathrm{L}_{\text {tabel }}$ 0,227 maka $\mathrm{H}_{\mathrm{a}}$ diterima. Hal ini berarti sampel berasal dari populasi berdistribusi normal.

Berdasarkan data hasil Pretest dan Posttest siswa Kelas 1 SD Negeri 1 Karangasem Kabupaten Grobogan. Sebagai subjek penelitian dilakukan perhitungan untuk menganalisis hasil Pretest dan Posttest. Pengujian Hipotesis berdasarkan hasil Pretest dan Posttest sebagai berikut

Tabel 4. Data Hasil Belajar

\begin{tabular}{|c|c|c|c|}
\hline NO & DATA & PRETEST & POSTTEST \\
\hline 1 & Jumlah & 790 & 1055 \\
\hline 2 & Rata-rata & 56,43 & 75,36 \\
\hline 3 & Md & 19 & \\
\hline 4 & $t_{\text {hitung }}$ & 16,466 & \\
\hline 5 & $t_{\text {tabel }}$ & 1,771 & \\
\hline
\end{tabular}


Berdasarkan perhitungan diperoleh $\mathrm{t}$ hitung sebesar 16,466 sedangkan $\mathrm{t}$ table dengan $\mathrm{db}=\mathrm{N}-1$ $=14-1=13$, dan taraf signifikan 0,05 sebesar 16,466. Karena t hitung $>t$ table yaitu $16,466>1,771$, maka $\mathrm{H} 0$ ditolak dan Ha diterima. Sehingga dapat dikatakan bahwa media kotak pas bangun ruang berpengaruh terhadap hasil belajar tema kegemaranku siswa kelas 1 SD N 1 Karangasem Kabupaten Grobogan.

Hasil dari penelitian secara keseluruhan telah mencapai indikator keberhasilan yang ditetapkan. Ketercapaian indikator keberhasilan pada hasil penelitian tersebut membuktikan bahwa, penelitian dengan menggunakan media pembelajaran Kotak Pas Bangun Ruang telah mencapai keberhasilan.

Berdasarkan perhitungan analisis statistika pada tahap sebelum diberi perlakuan, terlebih dahulu dilakukan uji normalitas awal. Uji normalitas digunakan untuk mengetahui subjek penelitian berdistribusi normal atau tidak normal. Berdasarkan perhitungan yang telah dilakukan diperoleh kesimpulan bahwa nilai pretest kelas I SD Negeri 1 Karangasem berdistribusi normal karena dari hasil perhitungan diperoleh $\mathrm{L}_{0}=0,1271$ dan $\mathrm{L}_{\text {tabel }}=0,227$ dengan taraf nyata atau $\alpha=5 \%$ dan $\mathrm{N}=14$. Dari data tersebut dapat disimpulkan bahwa $\mathrm{L}_{0}<\mathrm{L}_{\text {tabel }}$ atau $(0,1271<0,227)$, maka Ho diterima, sehingga sampel berasal dari populasi berdistribusi normal.

Pada tahap akhir dilakukan kembali uji normalitas dengan menggunakan posttest. Berdasarkan perhitungan yang telah dilakukan diperoleh kesimpulan bahwa nilai posttest kelas I SD Negeri 1 Karangasem berdistribusi normal karena dari hasil perhitungan diperoleh $\mathrm{L}_{0}=0,1451$ dan $\mathrm{L}_{\text {tabel }}=0,227$ dengan taraf nyata atau $\alpha=5 \%$ dan $\mathrm{N}=14$. Dari data tersebut dapat disimpulkan bahwa $\mathrm{L}_{0}<\mathrm{L}_{\text {tabel }}$ atau $(0,1451<0,227)$ maka $\mathrm{H}_{0}$ diterima, sehingga sampel berasal dari populasi berdistribusi normal.

Hasil penelitian dengan menggunakan media Kotak Pas Bangun Ruang menunjukkan bahwa ratarata nilai pretest sebesar 56,43 . Sedangkan hasil posttest sebesar 75,36 dengan persentase kenaikan sebesar 18,93\%. Hal ini dapat menunjukkan secara jelas bahwa media Kotak Pas Bangun Ruang dinyatakan dapat meningkatkan hasil belajar siswa kelas I pada tema kegemaranku. Hal tersebut diperkuat dengan hasil perhitungan uji-t hasil belajar diperoleh $t_{\text {hitung }}=16,466$ dengan nilai $t_{\text {tabel }} 1,771$, maka $t_{\text {hitung }}>t_{\text {tabelatau }} 16,466>1,771$. Sehingga media Kotak Pas Bangun Ruang dapat meningkatkan hasil belajar siswa tema kegemaranku siswa kelas I di SD Negeri 1 Karangasem Kabupaten Grobogan.

Perolehan hasil belajar menunjukan bahwa media Kotak Pas Bangun Ruang pada tema Kegemaranku dapat meningkatkan hasil belajar siswa. Sesuai dengan pendapat Gagne dalam Dahan (2006:2) bahwa belajar adalah proses dimana siswa berubah perilakunya sebagai akibat dari pengalaman. Sedangkan menurut Slameto (2013:2) hasil belajar adalah perubahan tingkah laku dalam proses belajar terjadi akibat interaksi yang dilakukan siswa dengan lingkungannya. Jadi hasil belajar merupakan pencapaian tujuan belajar dan hasil belajar sebagai produksi proses belajar. Pada pelaksanaan penelitian ini, siswa yang sebelumnya kurang memahami bentuk-bentuk bangun ruang, menjadi memahami dan membedakan bentuk-bentuk bangun ruang saat pembelajaran dan dalam kehidupan sehari-hari setelah menggunakan media Kotak Pas Bangun Ruang pada tema Kegemaranku.

Berdasarkan penelitian yang di lakukan oleh Sulistyanto (2013) menyatakan bahwa penggunaan media konkret dapat meningkatkan hasil belajar bangun ruang. Sedangkan menurut Haerul (2015) penggunaan peraga benda konkret dapat meningkatkan pemahaman matematikan materi volume bangun ruang. Jadi penggunaan media kongkret sangat berpengaruh terhadap peningkatan hasil belajar siswa materi bangun ruang. Sesuai dengan Hasil penelitian dengan menggunakan media Kotak Pas Bangun Ruang pada tema kegemaranku

Siswa kelas 1 masih berfikir secara konkret dan kental dengan zona bermain. Penggunaan media Kotak Pas Bangun Ruang menjadikan siswa lebih berinteraksi dalam proses pembelajaran, sehingga membuat siswa lebih semangat dan membuat hasil belajarnya meningkat. Hal ini sesuai dengan teori belajar Vygotsky dalam Henry Dkk, (2015:25) yang menekankan pada interaksi sosial sebagai sebuah mekanisme untuk mendukung perkembangan kognitif. Dengan interaksi sosial yang terjalin antar anggota kelompok, siswa lebih mudah memahami materi dengan bertanya dengan anggota kelompok yang lebih memahami materi tersebut. Sehingga dalam perkembangan kognitif yang dilihat dari hasil belajar siswa akan meningkat.

\section{Simpulan dan Saran}

Hasil penelitian dan analisis data menunjukkan bahwa Media Kotak Pas Bangun Ruang dapat meningkatkan hasil belajar siswa pada tema kegemaranku siswa kelas I SD N 1 Karangasem Kabupaten Grobogan.

Hal ini dapat dilihat darihasil nilai rata-rataPosttest meningkat dari hasil nilai rata-rata Pretest. Dimana nilai rata-rata Pretest adalah 56,43 sedangkan nilai rata-rata Posttest adalah 75,36. Analisis akhir dengan uji-t satu pihak diperoleh $t_{\text {hitung }}=16,446$ dan untuk $\alpha=5 \%$ dengan $\mathrm{db}=\mathrm{N}-1=14-1=13$ dilihat dari 
tabel distribusi $t$ diporoleh $t_{\text {tabel }}=1,771$. Perhitungan menunjukan bahwa $t_{\text {hitung }}>t_{\text {tabel }}$ atau $16,446>1,771$ maka $\mathrm{H}_{0}$ ditolak. Hipotesis pada penelitian ini diterima.

Beradsarkan kesimpulan di atas, saran yang dapat peneliti berikan sehubungan dengan hasil penelitian ini adalah Media Kotak Pas Bangun Ruang dapat menjadi alternatif pembelajaran yang dapat membuat siswa tidak jenuh dan merasa senang mengikuti pembelajaran, sehingga materi yang disampaikan dapat diserap dengan baik dan hasil belajar siswa diatas kriteria ketuntasan minimal yang sudah ditentukan.

\section{Daftar Rujukan}

Arikunto, Suharsimi. 2007. Prosedur Penelitian Suatu Pendekatan Praktik. Jakarta: Rineka Cipta.

Arikunto, Suharsimi. 2013. Dasar-Dasar Evaluasi Pendidikan. Jakarta: Bumi Aksara.

Arikuto, Suharsimi. 2014. Prosedur Penelitian Suatu Pendekatan Praktik. Jakarta: Rineka Cipta.

Arikunto, Suharsimi. 2015. Dasar-dasar Evaluasi Pendidikan. Jakarta: Bumi Aksara.

Arsyad, Azhar. 2014. Media Pembelajaran. Jakarta: PT RajaGrafindo Persada.

Arsyad, Azhar. 2016. Media Pembelajaran. Jakarta: PT RajaGrafindo Persada.

Ayuwanti, Irma. 2016. Meningkatkan Aktivitas Dan Hasil Belajar Matematika Menggunakan Model Pembelajaran Kooperatif Tipe Group Investigation Di Smk Tuma'ninah Yasin Metro . Jurnal SAP Vol. 1 No. 2 Desember 2016

Daryanto. 2013. Media Pembelajaran. Yogyakarta: Gava Media.

Hamalik, Oemar. 2009. Proses Belajar Mengajar. Jakarta: PT Bumi Aksara.

Heruman. 2014. Model Pembelajaran Matematika Di Sekolah Dasar. Bandung: PT Remaja Rosdakarya.

Haerul. 2015. Peningkatan Pemahaman Konsep Matematika Materi Volume Bangun Ruang Menggunakan Peraga Benda Konkret Pada Siswa Kelas VI MI Al Bashirah Makasar.

Purwanto, M Ngalim. 2003. Ilmu Pendidikan Teoritis Dan Praktis. Bandung: PT Remaja Rosdakarya.

Permendiknas. 2013. UU RI No. 20 tahun 2003 tentang Sistem Pendidikan nasion

Kadir, \& Asroh. 2014. Pembelajaran Tematik. Jakarta: Rajawali Pers.

Kurniawan, Deni. 2014. Pembelajaran Terpadu tematik: Teori, dan Penilaian. Bandung : Alfabeta, cv

Khotimah, Nurul. 2018. Pengaruh Penggunaan Media Realita Terhadap Hasil Belajar Matemmatika Materi Bangun Ruang Siswa Kelas IV di di SD N Sriwaylangsep Kecamatan Kalirejo. Journal Pedagogi. 8 (5) (2018).

Maslikan. 2017. Penggunaan Media Pembelajaran Kotak Dan Kartu Misterius (Kokami) Untuk Meningkatkan Aktifitas Dan Ketuntasan Belajar Peserta Didik Pada Pokok Bahasan Bola Volly Di Kelas Xii Mipa 1 Sma Negeri 2 Pekanbaru. Jurnal Pendidikan Ekonomi Akuntansi FKIP UIR Vol 5 No 2 Tahun 2017

Sulistyanto, Wakit. 2013. Upaya mrningkatkan Hasil Belajar Bangun Ruang Menggunakan Media Konkret Pada Siswa Kelas IV SD N Kraton Yogyakarta. Journal Student UNY. 2 (14) (2013).

Sukmadinata, Nana Syaodih. 2009. Landasan Psikologi Proses Pendidikan. Bandung: PT Remaja Rosdakarya. 
Sundayana, Rostiana. 2015. Media dan Alat Peraga dalam Pembelajaran Matematika. Bandung: Alfabeta, cV.

Sugiyono. 2015. Metode Penelitian Pendidikan. Bandung: Alfabeta, cv.

Suwangsih, Erna, dan Tiurlina. 2006. Model Pembelajaran Matematika. Bandung: UPI Press.

Umi, Kenyo Nuswantoro. 2017. Meningkatkan Hasil Belajar Matematika Materi Bangun Ruang dan Bangun Datar dengan Menggunakan Alat Peraga Sederhana Pada Siswa Kelas IV SDIT Miftahussalam Mijen Kota Semarang Tahun Pelajaran 2015/2016. 